\title{
Radioactivity of Five Typical General Industrial Solid Wastes and its Influence in Solid Waste Recycling
}

\author{
Zhihui Shen ${ }^{1,2,3,4}$, Qin Zhang ${ }^{2,3,4, *}$, Wei Cheng ${ }^{2,3,4}$ and Qianlin Chen ${ }^{2,3,4,5}$ \\ 1 College of Resources and Environmental Engineering, Guizhou University, Guiyang 550025, China; \\ zhshen@gzu.edu.cn \\ 2 College of Mining, Guizhou University, Guiyang 550025, China; wcheng1@gzu.edu.cn (W.C.); \\ qlchen@gzu.edu.cn (Q.C.) \\ 3 National \& Local Joint Laboratory of Engineering for Effective Utilization of Regional Mineral Resources \\ from Karst Areas, Guiyang 550025, China \\ 4 Guizhou Key Laboratory of Comprehensive Utilization of Non-metallic Mineral Resources, \\ Guiyang 550025, China \\ 5 School of Chemistry and Chemical Engineering, Guizhou University, Guiyang 550025, China \\ * Correspondence: zq6736@163.com
}

Received: 14 January 2019; Accepted: 5 March 2019; Published: 9 March 2019

check for updates

\begin{abstract}
The level of radionuclides is an important index for the preparation of building materials from industrial solid waste. In order to investigate the radiological hazard of five kinds of typical general industrial solid wastes in Guizhou, China, including fly ash (FA), red mud (RM), phosphorus slag (PS), phosphogypsum (PG), and electrolytic manganese residue (EMR), the radiation intensity and associated radiological impact were studied. The results show that concentrations of ${ }^{238} \mathrm{U},{ }^{235} \mathrm{U}$, ${ }^{232} \mathrm{Th},{ }^{226} \mathrm{Ra},{ }^{210} \mathrm{~Pb}$, and ${ }^{40} \mathrm{~K}$ for different samples vary widely. The concentration of ${ }^{238} \mathrm{U}$ was both positively correlated with ${ }^{235} \mathrm{U}$ and ${ }^{226} \mathrm{Ra}$, and the uranium contents in the measured samples were all of natural origin. The radiation levels of PG, EMR, EMR-Na (EMR activated by $\mathrm{NaOH}$ ), and EMR-Ca (EMR activated by $\mathrm{Ca}(\mathrm{OH})_{2}$ ) were all lower than the Chinese and the world's recommended highest levels for materials allowed to be directly used as building materials. The values of the internal and external illumination index ( $\mathrm{I}_{\mathrm{Ra}}$ and $\mathrm{I}_{\gamma}$, respectively) for FA and RM were higher $\left(\mathrm{I}_{\mathrm{Ra}}>1.0\right.$ and $\mathrm{I}_{\gamma}>1.3$ for FA, $\mathrm{I}_{\mathrm{Ra}}>2.0$ and $\mathrm{I}_{\gamma}>2.0$ for $\left.\mathrm{RM}\right)$. The radium equivalent activity $\left(\mathrm{Ra}_{\mathrm{eq}}\right)$, indoor and outdoor absorbed dose $\left(D_{\text {in }}\right.$ and $D_{\text {out }}$, respectively), and corresponding annual effective dose rate ( $E_{\text {in }}$ and $E_{\text {out }}$ ) of RM, PS, and FA were higher than the recommended limit values (i.e., $370 \mathrm{~Bq} / \mathrm{kg}$, $84 \mathrm{nGy} / \mathrm{h}, 59 \mathrm{nGy} / \mathrm{h}, 0.4 \mathrm{mSv} / \mathrm{y}$, and $0.07 \mathrm{mSv} / \mathrm{y}$, respectively), resulting from the higher relative contribution of ${ }^{226} \mathrm{Ra}$ and ${ }^{232} \mathrm{Th}$. The portion of RM, FA, and PS in building materials should be less than $75.44 \%, 29.72 \%$, and $66.01 \%$, respectively. This study provides quantitative analysis for the safe utilization of FA, RM, PS, PG, and EMR in Guizhou building materials.
\end{abstract}

Keywords: general industrial solid waste; building materials; natural radioactivity; activity concentration; radiological influence

\section{Introduction}

General industrial solid waste refers to waste discharged in various industrial production processes, such as the waste of the electric power industry, aluminum industry, phosphorus chemical industry, coal chemical industry, metallurgy, and so forth. This includes fly ash (FA), red mud (RM), phosphogypsum (PG), phosphorus slag (PS), and electrolytic manganese residue (EMR). At present, most general industrial solid waste is mainly used as raw materials for construction, such as cement and concrete, as well as environmental functional materials and a source of valuable elements [1]. In 2016, the comprehensive utilization of general industrial solid waste in China accounted for $48.0 \%$ of 
the country's total utilization and disposal, and disposal and storage accounted for $21.2 \%$ and $30.7 \%$ [2], respectively. As mineral resources usually contain natural radionuclides, the activity of radionuclides, such as FA, PS, PG, RM, and EMR, in some industrial solid wastes tends to increase after roasting or electrolyzation. When those general industrial solid wastes are used to prepare building materials, the gamma rays released by radionuclides can pose a radiation hazard to the living environment.

Natural radionuclides, ubiquitously spread in the natural environment [3,4], consist of three well-known radioactive series, that is, the actinium series originating from ${ }^{235} \mathrm{U}$, the uranium series originating from ${ }^{238} \mathrm{U}$, and the thorium series originating from ${ }^{232} \mathrm{Th}$. In addition, there are several isolated radionuclides, such as ${ }^{40} \mathrm{~K}[5,6]$. The radioactive decay chains of ${ }^{232} \mathrm{Th},{ }^{238} \mathrm{U},{ }^{235} \mathrm{U}$, and ${ }^{40} \mathrm{~K}$ are the main contributors to the dose of natural radiation [7]. When the ratio of ${ }^{235} \mathrm{U} /{ }^{238} \mathrm{U}$ is less than $1 \%$, the contribution of ${ }^{235} U$ to the environmental dose is very small [8]. Since $98.5 \%$ of the radiological effects from uranium series nuclides are produced by ${ }^{226} \mathrm{Ra}$ and its decay products, the radiation from ${ }^{238} \mathrm{U}$ and the other ${ }^{226} \mathrm{Ra}$ precursors are negligible [9]. When industrial solid waste is used to prepare building materials, radionuclides in the environment can be determined by the natural radioactivity level of building materials or the industrial solid waste. Thus, radiation hazards can be assessed. At present, the internal and external exposure index, radium equivalent activity, and indoor and outdoor absorbed dose rate are commonly used indicators in evaluating radionuclide radiation hazards.

The average activity concentrations of ${ }^{226} \mathrm{Ra},{ }^{232} \mathrm{Th}$, and ${ }^{40} \mathrm{~K}$ in FA, RM, PG, and EMR samples from similar studies in different parts of the world are illustrated in Table 1. As shown in Table 1, it is suggested that the mean activity concentrations of ${ }^{226}$ Ra for FA in Turkey, Greece, and China (Xiangyang) are 360, 815, and $441 \mathrm{~Bq} / \mathrm{kg}$, respectively, higher than those in other countries. Concentrations of ${ }^{40} \mathrm{~K}$ in EU countries are generally higher than in others. In terms of RM, the average activity concentrations of ${ }^{226} \mathrm{Ra},{ }^{232} \mathrm{Th}$, and ${ }^{40} \mathrm{~K}$ in Australia and Jamaica are notably higher than those in other countries. In addition, ${ }^{226} \mathrm{Ra}$ is the main nuclide for PG in Israel, Spain, Korea, Egypt, and Turkey, while the concentrations of ${ }^{226} \mathrm{Ra},{ }^{232} \mathrm{Th}$, and ${ }^{40} \mathrm{~K}$ for PG in South Africa are relatively balanced. It can be concluded from Table 1 that radionuclide activity concentrations differ from one location to another.

Table 1. The obtained average activity concentrations of ${ }^{226} \mathrm{Ra},{ }^{232} \mathrm{Th}$, and ${ }^{40} \mathrm{~K}$ in FA, RM, PG, and EMR samples from similar studies in different parts of the world (unit: $\mathrm{Bq} / \mathrm{kg}$ ).

\begin{tabular}{|c|c|c|c|c|c|}
\hline \multirow{2}{*}{ Country } & \multirow{2}{*}{ Sample Type } & \multicolumn{3}{|c|}{ Activity Concentration (Bq/kg) } & \multirow{2}{*}{ Reference } \\
\hline & & ${ }^{226} \mathrm{Ra}$ & ${ }^{232} \mathrm{Th}$ & ${ }^{40} \mathrm{~K}$ & \\
\hline India & & 119 & 147 & 352 & [10] \\
\hline Turkey & & 360 & 102 & 517 & [11] \\
\hline Hungary & & 178 & 55 & 387 & [12] \\
\hline Greece & & 815 & 56 & 400 & [13] \\
\hline Czech Rep. & & 146 & 86 & 669 & [13] \\
\hline Germany & FA & 164 & 94 & 517 & [13] \\
\hline Italy & & 170 & 140 & 400 & [13] \\
\hline Poland & & 200 & 118 & 798 & [13] \\
\hline Romania & & 219 & 116 & 595 & [13] \\
\hline China (Baoji) & & 112 & 148 & 386 & [14] \\
\hline China (Xiangyang) & & 441 & 110 & 510 & [15] \\
\hline Turkey & & 210 & 539 & 112 & [13] \\
\hline Hungary & & 301 & 295 & 50 & [13] \\
\hline Greece & & 244 & 364 & 57 & [13] \\
\hline Germany & $\mathbf{R M}$ & 171 & 318 & 215 & [13] \\
\hline Italy & & 97 & 118 & 115 & [13] \\
\hline Australia & & 310 & 1350 & 350 & [16] \\
\hline Jamaica & & 1047 & 350 & 335 & [17] \\
\hline
\end{tabular}


Table 1. Cont

\begin{tabular}{|c|c|c|c|c|c|}
\hline \multirow{2}{*}{ Country } & \multirow{2}{*}{ Sample Type } & \multicolumn{3}{|c|}{ Activity Concentration (Bq/kg) } & \multirow{2}{*}{ Reference } \\
\hline & & ${ }^{226} \mathrm{Ra}$ & ${ }^{232} \mathrm{Th}$ & ${ }^{40} \mathrm{~K}$ & \\
\hline Turkey & \multirow{8}{*}{ PG } & 436 & 9 & 13 & [18] \\
\hline Bangladesh & & 234 & 21 & 108 & [19] \\
\hline Egypt & & 596 & 6 & 2 & [20] \\
\hline Jordan & & 376 & 4 & 40 & [21] \\
\hline Korea & & 618 & 9 & 24 & [22] \\
\hline Israel & & 747 & 14 & 63 & [23] \\
\hline Spain & & 647 & 8 & 33 & [24] \\
\hline South Africa & & 109 & 189 & $>100$ & [25] \\
\hline Hungary & \multirow{2}{*}{ EMR } & 52 & 40 & 607 & [26] \\
\hline China (Chongqing) & & 37 & 58 & 631 & [27] \\
\hline
\end{tabular}

Additionally, many studies have analyzed the radiation hazards of industrial solid wastes. Mamta Gupta et al. [10] reported that the radium equivalent activity of the FA from a thermal power plant in India was $353.9 \mathrm{~Bq} / \mathrm{kg}$, which is close to the maximum upper limit of $370 \mathrm{~Bq} / \mathrm{kg}$. L. Taoufiq et al. [28] characterized the radioactivity of FA from a thermal power plant in Morocco, and found that the radium equivalent activity was $241-298 \mathrm{~Bq} / \mathrm{kg}$, which is lower than $370 \mathrm{~Bq} / \mathrm{kg}$. In summary, the radionuclide activity concentrations and associated radiation hazards differ from one location to another. Different isotopes concentration in ores is a result of different conditions, including the metallogenetic body, formation age, epigenetic transformation, and so forth, during deposit formation in different regions. Therefore, the radioactive level of general industrial solid wastes in other regions cannot be used as the reference for Guizhou, China.

The dominant mineral resources, such as coal, phosphorite, bauxite, and manganese, are found in Guizhou. During the development and utilization process for these resources, a large amount of general solid waste including FA, PS, PG, RM, and EMR is accumulated. According to the data from the China statistical yearbook as shown in Table 2, from 2012 to 2017, the national generation volume of general industrial solid wastes varied from 3.09 to 3.32 billion tons, while the generation of Guizhou province varied from 0.071 to 0.094 billion tons. The substantial discharge and stockpiling of those aforementioned industrial solid wastes result in serious environmental pollution. It is vital to find an optimal solution for applying the solid wastes. The study of natural radionuclides and their radiation hazards is of great significance for the comprehensive utilization of industrial solid waste resources in the field of building materials.

Table 2. Generation of general industrial solid waste during 2012-2017, in Guizhou, China (unit: billion tons).

\begin{tabular}{cccc}
\hline Year & China & Guizhou & Reference \\
\hline 2012 & 3.290 & 0.078 & {$[29]$} \\
2013 & 3.277 & 0.082 & {$[30]$} \\
2014 & 3.256 & 0.074 & {$[31]$} \\
2015 & 3.271 & 0.071 & {$[32]$} \\
2016 & 3.092 & 0.078 & {$[33]$} \\
2017 & 3.316 & 0.094 & {$[34]$} \\
\hline
\end{tabular}

In this study, the radionuclide activity of five typical general industrial solid wastes including FA, PS, RM, PG, and EMR in Guizhou, China, was measured using a gamma spectrometry technique. The radioactivity level and associated radiation hazard of these industrial solid wastes were evaluated using indicators such as the internal and external irradiation index ( $I_{\mathrm{Ra}}$ and $I_{\gamma}$, respectively), radium equivalent ratio $\left(R a_{\mathrm{eq}}\right)$, indoor and outdoor external dose ( $D_{\text {in }}$ and $D_{\text {out }}$, respectively), and indoor and outdoor annual effective dose rate ( $E_{\text {in }}$ and $E_{\text {out }}$, respectively). The maximum dosages of solid wastes in building materials were calculated. This study, through radiation evaluation, hopes to provide a 
mixing amount reference for the aforementioned solid wastes for building materials that meet the radiation limitation requirements.

\section{Materials and Methods}

\subsection{Samples}

The samples in this study include: PS, FA, RM, PG, EMR, electrolytic manganese slag activated by $\mathrm{NaOH}$ (EMR-Na), and electrolytic manganese slag activated by $\mathrm{Ca}(\mathrm{OH})_{2}$ (EMR-Ca). Sample PS taken from a building material company in Guizhou, China, was produced using the electric furnace process of preparing yellow phosphorus, which is grayish white or white and partially agglomerated. Sample FA obtained from a coal-burning power plant in Guizhou was black. Sample RM produced by Bayer process from an aluminum company in Guizhou was light red. Sample PG obtained from a phosphorus chemical company in Guizhou was gray and very agglomerated. Sample EMR obtained from an electrolytic manganese plant in Guizhou was a black, fresh slurry. EMR has a certain potential gelling activity with a small amount of silicon and aluminum. The alkaline substance can better excite the potential activity and form a hydrated silicate and aluminate product with hydration characteristics, resulting in the gelling properties of EMR. The alkali-activated EMR can replace part of the cement used to prepare building materials. Previous studies showed that $\mathrm{NaOH}$ and $\mathrm{Ca}(\mathrm{OH})_{2}$ have better activation effects on EMR. Therefore, EMR-Na used in this study was obtained by mixing $75 \mathrm{~g}$ of fresh EMR, 15 wt. $\% \mathrm{NaOH}$ (accounting for EMR), and $100 \mathrm{~mL}$ of tap water in a $500 \mathrm{~mL}$ stirred tank and stirring this mixture for $20 \mathrm{~min}$. EMR-Ca was obtained by mixing $100 \mathrm{~g}$ of fresh EMR, $20 \mathrm{wt} . \% \mathrm{Ca}(\mathrm{OH})_{2}$ (accounting for EMR), and $100 \mathrm{~mL}$ of tap water in a $500 \mathrm{~mL}$ stirred tank and stirring this mixture for $15 \mathrm{~min}$.

The moisture contents of PS, FA, RM, PG, and EMR were $4.29 \%, 4.13 \%, 5.01 \%, 20.73 \%$, and 15.7\%, respectively. The densities of PS, FA, RM, PG, EMR, EMR-Na, and EMR-Ca were 3.06, 2.33, $3.01,2.57,2.31,2.35$, and $2.48 \mathrm{~g} / \mathrm{cm}^{3}$, respectively. Major components in seven solid wastes were analyzed by using X-ray fluorescence (XRF, PANalytical Axios mA $\times 4 \mathrm{KW}$, Malvern Panalytical, Almelo, The Netherlands), and the results are illustrated in Table 3. As shown in Table 3, PS, RM, FA are mainly composed of $\mathrm{CaO}, \mathrm{SiO}_{2}, \mathrm{Al}_{2} \mathrm{O}_{3}$, and $\mathrm{Fe}_{2} \mathrm{O}_{3}$ [35], $\mathrm{PG}$ is composed of $\mathrm{CaO}, \mathrm{SiO}_{2}, \mathrm{Al}_{2} \mathrm{O}_{3}$, and $\mathrm{SO}_{3}$ [36], while $\mathrm{CaO}, \mathrm{SiO}_{2}, \mathrm{Al}_{2} \mathrm{O}_{3}, \mathrm{Mn}$, and $\mathrm{S}$ are the main components in EMR, EMR-Na, and EMR-Ca.

Table 3. Major components in seven solid wastes.

\begin{tabular}{cccccccc}
\hline \multirow{2}{*}{ Component } & \multicolumn{7}{c}{ Concentration (\%) } \\
\cline { 2 - 8 } & PS & RM & FA & PG & EMR & EMR-Na & EMR-Ca \\
\hline $\mathrm{CaO}$ & 44.77 & 14.35 & 2.83 & 34.07 & 7.32 & 9.1 & 15.43 \\
$\mathrm{Fe}_{2} \mathrm{O}_{3}$ & 0.45 & 21.53 & 2.83 & 0.20 & - & - & - \\
$\mathrm{Al}_{2} \mathrm{O}_{3}$ & 5.55 & 20.89 & 14.75 & 0.13 & 8.85 & 11.27 & 7.99 \\
$\mathrm{SiO}_{2}$ & 37.81 & 16.75 & 45.72 & 5.29 & 22.85 & 30.29 & 20.35 \\
$\mathrm{MgO}$ & 2.61 & 1.55 & 1.18 & 0.01 & 1.86 & 2.42 & 1.80 \\
$\mathrm{P}_{2} \mathrm{O}_{5}$ & 2.86 & 0.31 & - & 0.75 & - & - & - \\
$\mathrm{TiO}_{2}$ & - & 4.59 & 1.74 & - & 0.25 & 0.33 & 0.21 \\
$\mathrm{~K}_{2} \mathrm{O}$ & 1.43 & 0.98 & 1.24 & - & 1.75 & 2.22 & 1.66 \\
$\mathrm{Na}_{2} \mathrm{O}$ & 0.33 & 4.93 & 0.55 & - & 0.14 & 0.42 & 0.12 \\
$\mathrm{SO}$ & - & 1.19 & - & 40.24 & - & - & - \\
$\mathrm{Mn}$ & - & - & - & - & 4.92 & 5.57 & 6.25 \\
$\mathrm{~S}$ & - & - & - & - & 8.19 & 3.2 & 7.08 \\
$\mathrm{Others}$ & 0.04 & 12.04 & 17.03 & 19.31 & 2.88 & 3.75 & 2.18 \\
\hline
\end{tabular}




\subsection{Methods}

\subsubsection{Radioactivity Measurement}

All samples were aggregated, identified, and oven-dried to constant weight in the laboratory, then grounded to a particle size of less than $0.075 \mathrm{~mm}$. Each sample was homogenized and dried in an oven at $105{ }^{\circ} \mathrm{C}$ for $3 \mathrm{~h}$ to remove moisture. Then, $200 \mathrm{~g}$ of each sample were weighed and placed into a cylinder measuring sample box with a diameter of $35 \mathrm{~mm}$ and a height of $20 \mathrm{~mm}$, then sealed for eight weeks to achieve radioactive secular equilibrium between ${ }^{226} \mathrm{Ra}$ and its daughters. The measurements of activity concentrations were carried out at the Institute of Geochemistry, Chinese Academy of Sciences, using a vertical closed coaxial HPGe detector (GX6020, CANBERRA, Oak Ridge, TN, USA). The detector has an energy range of $3 \mathrm{keV}$ to $10 \mathrm{MeV}$, with an energy resolution of $2.0 \mathrm{keV}$. The relative efficiency is $60 \%$ at $1332 \mathrm{keV} \gamma$-ray, and the peak-to-Compton ratio is 66:1. The actual energy range used to test the samples was 35-3000 keV. The measurement time for each sample was set as 180,000 s. The test data was collated and analyzed using management software OpenEMS with a data management system (RDBMS). To reduce the gamma ray background, a cylindrical lead shield detector was used to absorb X-rays, which contains two inner concentric cylinders of copper and aluminum. The calibration sources with an energy range covering nuclides ${ }^{238} \mathrm{U},{ }^{226} \mathrm{Ra}$, ${ }^{232} \mathrm{Th},{ }^{40} \mathrm{~K},{ }^{241} \mathrm{Am},{ }^{137} \mathrm{Cs}$, and ${ }^{60} \mathrm{Co}$ were used for the determination of the detection efficiency of the measurement system, and the typically obtained values were within $6 \%$ of certified values.

The $\gamma$-ray lines that were used to measure the activities for nuclides were represented mainly by gamma-ray-emitting nuclei in the decay series of ${ }^{232} \mathrm{Th},{ }^{226} \mathrm{Ra}$, and ${ }^{40} \mathrm{~K}$. The ${ }^{40} \mathrm{~K}$ and ${ }^{210} \mathrm{~Pb}$ were determined from their single photo peaks of $1460 \mathrm{keV}(1.2 \%)$ and $46.5 \mathrm{keV}(4.26 \%)$, respectively. The ${ }^{238} \mathrm{U}$ and ${ }^{232} \mathrm{Th}$ are not gamma ray emitters. However, it is possible to measure the gamma rays of their decay products. The decay product taken for ${ }^{238} \mathrm{U}$ was ${ }^{234} \mathrm{Th}(63.3 \mathrm{keV}(3.81 \%))$. The intensity of gamma rays emitted by ${ }^{232} \mathrm{Th}$ is very weak, and its decay product ${ }^{228} \mathrm{Ra}$ has a long half-life without gamma rays. The half-life of ${ }^{228} \mathrm{Ac}$, the daughter of ${ }^{228} \mathrm{Ra}$, is $6.13 \mathrm{~h}$. According to the literature, Th and Ra both have affinity for silicates [37]. Moreover, some studies have shown that the activities of ${ }^{232} \mathrm{Th}$ and ${ }^{228} \mathrm{Ra}$ in solid wastes such as red mud, phosphogypsum, and fly ash are approximately balanced [38-40]. Therefore, the equilibrium between ${ }^{232} \mathrm{Th}$ and ${ }^{228} \mathrm{Ra}$ was assumed, and the ${ }^{232} \mathrm{Th}$ was determined using ${ }^{208} \mathrm{Tl}(583.2 \mathrm{keV}(30.78 \%)$ and $2614.5 \mathrm{keV}(35.7 \%))$ and ${ }^{228} \mathrm{Ac}(911.2 \mathrm{keV}(26.6 \%))$. In addition, the ${ }^{214} \mathrm{~Pb}(351.9 \mathrm{keV}(35.8 \%)]$ and ${ }^{214} \mathrm{Bi}[609.3 \mathrm{keV}(45 \%))$ were used to determine the ${ }^{226} \mathrm{Ra}$, and the decay product taken for ${ }^{235} \mathrm{U}$ was ${ }^{235} \mathrm{U}(185.7 \mathrm{keV}(57.5 \%))$. As there is an interference between $185.7 \mathrm{keV}$ from ${ }^{235} \mathrm{U}$ and $186.2 \mathrm{keV}$ from ${ }^{226} \mathrm{Ra}$, the ${ }^{235} \mathrm{U}$ activity can be deduced from the $186 \mathrm{keV}$ multiplet after removal of the ${ }^{226} \mathrm{Ra}$ contribution. Thus, the activity concentration of ${ }^{235} \mathrm{U}$ radionuclide is given by Equation (1) [41]:

$$
A_{\mathrm{U}-235}=1.75 \times \frac{C R_{\mathrm{total}(186 \mathrm{keV})}}{\varepsilon_{186 \mathrm{keV}}}-0.06 \mathrm{~A}_{\mathrm{Ra}-226}
$$

where $C R$ and $C R_{\text {total}(186 \mathrm{keV})}$ are calculated by using Equations (2) and (3):

$$
\begin{gathered}
C R=A \times B R \times \varepsilon \\
C R_{\text {total }(186 \mathrm{keV})}=C R_{\mathrm{Ra}-226}+C R_{\mathrm{U}-235}
\end{gathered}
$$

where $C R$ is the counting rate in full-energy peak in count/s, $C R_{\text {total(186 keV) }}$ is the counting rate for the $186 \mathrm{keV}$ multiple, $A$ is the activity of radionuclide in $\mathrm{Bq} / \mathrm{kg}$, $\mathrm{BR}$ is the branching ratio or the gamma-ray emission rate, $\varepsilon$ is the detection efficiency. ${ }^{226} \mathrm{Ra}$ and ${ }^{235} \mathrm{U}$ contribute about $58 \%$ and $42 \%$ of the total count rate of the $186 \mathrm{keV}$ peak with the existence of equilibrium, respectively [42]. 


\subsubsection{Internal and External Illumination Index}

The internal exposure index $\left(I_{\mathrm{Ra}}\right)$ refers to the specific activity ratio of ${ }^{226} \mathrm{Ra}$ in the building materials to the ${ }^{226} \mathrm{Ra}$ limit specified in the national standard (GB6566-2010) [43]. The external radiation index $\left(I_{\gamma}\right)$ refers to the sum of the specific activity ratio of ${ }^{226} \mathrm{Ra},{ }^{232} \mathrm{Th}$, and ${ }^{40} \mathrm{~K}$ in building materials to their respective standard limits. The $I_{\mathrm{Ra}}$ and $I_{\gamma}$ were calculated by using Equations (4) and (5):

$$
\begin{gathered}
I_{\mathrm{R}_{\mathrm{a}}}=\frac{C_{\mathrm{R}_{\mathrm{a}}}}{200} \\
I_{\gamma}=\frac{C_{\mathrm{R}_{\mathrm{a}}}}{370}+\frac{C_{\mathrm{Th}}}{260}+\frac{C_{\mathrm{K}}}{4200}
\end{gathered}
$$

where $C_{\mathrm{Ra}}, C_{\mathrm{Th}}$, and $C_{\mathrm{K}}$ are the mean radioactivity concentrations of ${ }^{226} \mathrm{Ra},{ }^{232} \mathrm{Th}$, and ${ }^{40} \mathrm{~K}(\mathrm{~Bq} / \mathrm{kg})$, respectively. The specific activity limit of ${ }^{226} \mathrm{Ra}$ in building materials specified in the GB6566-2010 is $200 \mathrm{~Bq} / \mathrm{kg}$, considering only the internal irradiation conditions. The prescribed limits were 370,260 , and $4200 \mathrm{~Bq} / \mathrm{kg}$ for ${ }^{226} \mathrm{Ra},{ }^{232} \mathrm{Th}$, and ${ }^{40} \mathrm{~K}$, respectively, in building materials when they exist separately under the external irradiation condition.

\subsubsection{Radium Equivalent Activity}

The distribution of ${ }^{226} \mathrm{Ra},{ }^{232} \mathrm{Th}$, and ${ }^{40} \mathrm{~K}$ in building materials is not uniform [44]. The radium equivalent activity $\left(R a_{\mathrm{eq}}\right)$ [45] was used to compare the relative gamma radioactivity of ${ }^{226} \mathrm{Ra},{ }^{232} \mathrm{Th}$, and ${ }^{40} \mathrm{~K}$ in building materials. It has been estimated that $1 \mathrm{~Bq} / \mathrm{kg}$ of ${ }^{226} \mathrm{Ra}, 0.7 \mathrm{~Bq} / \mathrm{kg}$ of ${ }^{232} \mathrm{Th}$, and $13 \mathrm{~Bq} / \mathrm{kg}$ of ${ }^{40} \mathrm{~K}$ produce the same gamma ray dose $[46,47]$. Thus, the radium equivalent activities $\left(R a_{\mathrm{eq}}\right)$ can be estimated using Equation (6) [48-50]:

$$
R a_{\mathrm{eq}}=C_{\mathrm{Ra}}+1.43 C_{\mathrm{Th}}+0.077 C_{\mathrm{K}}
$$

\subsubsection{Indoor External Dose $\left(D_{\text {in }}\right)$ and Outdoor External Dose $\left(D_{\text {out }}\right)$}

An irradiation scenario is required to evaluate the ${ }^{226} \mathrm{Ra},{ }^{232} \mathrm{Th}$, and ${ }^{40} \mathrm{~K}$ absorbed doses produced by the building materials. The European Commission proposed that the length, width, and height of the concrete room are 4, 5, and $2.8 \mathrm{~m}$, respectively. The thickness and density of the wall are $20 \mathrm{~cm}$ and $2350 \mathrm{~kg} \cdot \mathrm{m}^{-3}$, respectively [51]. Then, the indoor external dose $D_{\text {in }}$ could be calculated by using Equation (7):

$$
D_{\text {in }}(\mathrm{nGy} / \mathrm{h})=0.92 C_{\mathrm{Ra}}+1.1 C_{\mathrm{Th}}+0.081 C_{\mathrm{K}}
$$

To assess the dose of radiation from building materials in a room, the portion from natural radiation needs to be subtracted. According to the survey results of the Chinese National Environmental Protection Department, the weighted mean by area and population are 62.8 and $62.1 \mathrm{nGy} \cdot \mathrm{h}^{-1}$, respectively. Taking $62.1 \mathrm{nGy} \cdot \mathrm{h}^{-1}$ as the natural radiation background value, the calculated absorbed dose rate should be reduced by 62.1 [52].

The outdoor external dose $\left(D_{\text {out }}\right)$ assessed from ${ }^{226} \mathrm{Ra},{ }^{232} \mathrm{Th}$, and ${ }^{40} \mathrm{~K}$ was supposed to be equally distributed at $1 \mathrm{~m}$ above the ground surface. Therefore, the $D_{\text {out }}$ was calculated using Equation (8) [53]:

$$
D_{\text {out }}(\mathrm{nGy} / \mathrm{h})=0.462 C_{\mathrm{Ra}}+0.604 C_{\mathrm{Th}}+0.0417 C_{\mathrm{K}} .
$$

\subsubsection{Annual Effective Dose Rate}

Buildings are the main places for daily activities of human beings, and the indoor and outdoor occupancy factors are 0.8 and 0.2 , respectively (i.e., $80 \%$ and $20 \%$ of the time they are occupied indoors and outdoors, respectively) $[54,55]$. The conversion factor from the absorbed dose in the air to the effective dose received by the individual is 0.7 [56]. The annual indoor effective dose rate 
$\left(E_{\text {in }}\right)$ and annual outdoor effective dose rate $\left(E_{\text {out }}\right)$ can be calculated using Equations (9) and (10), respectively [55,57]:

$$
\begin{gathered}
E_{\text {in }}=D_{\text {in }} \times 365 \times 24 \mathrm{~h} \times 0.8 \times 0.7(\mathrm{~Sv} / \mathrm{Gy})=D_{\text {in }} \times 4905 \times 10^{-6}(\mathrm{mSv} / \mathrm{y}) \\
E_{\text {out }}=D_{\text {out }} \times 365 \times 24 \mathrm{~h} \times 0.2 \times 0.7(\mathrm{~Sv} / \mathrm{Gy})=D_{\text {out }} \times 1226 \times 10^{-6}(\mathrm{mSv} / \mathrm{y})
\end{gathered}
$$

\subsubsection{Maximum Dosage of Solid Waste in Building Materials}

The maximum dosage of solid waste in building materials $f_{s}$ can be calculated by using Equations (11) and (12):

$$
\begin{gathered}
\frac{\mathrm{f}_{\mathrm{s}} \cdot C_{\mathrm{Ra}}+\left(1-\mathrm{f}_{\mathrm{s}}\right) \cdot C_{\mathrm{Ra}}^{\prime}}{200} \leq 1.0 \\
\frac{\mathrm{f}_{\mathrm{s}} \cdot C_{\mathrm{Ra}}+\left(1-\mathrm{f}_{\mathrm{s}}\right) \cdot C_{\mathrm{Ra}}^{\prime}}{370}+\frac{\mathrm{f}_{\mathrm{s}} \cdot C_{\mathrm{Th}}+\left(1-\mathrm{f}_{\mathrm{s}}\right) \cdot C_{\mathrm{Th}}^{\prime}}{260}+\frac{\mathrm{f}_{\mathrm{s}} \cdot C_{\mathrm{K}}+\left(1-\mathrm{f}_{\mathrm{s}}\right) \cdot C_{\mathrm{K}}^{\prime}}{4200} \leq 1.0
\end{gathered}
$$

where $C_{\mathrm{Ra}^{\prime}}^{\prime} C_{\mathrm{Th}}^{\prime}$, and $C_{\mathrm{K}}^{\prime}$ are the mean radioactivity concentrations of ${ }^{226} \mathrm{Ra},{ }^{232} \mathrm{Th}$, and ${ }^{40} \mathrm{~K}$ (in Bq/kg) for other components in building materials, respectively. When the ratio of $C_{\mathrm{Ra}^{\prime}}^{\prime} C_{\mathrm{Th}^{\prime}}^{\prime}$ and $C_{\mathrm{K}}^{\prime}$ are all meant to be zero, the ratio of $f_{s}$ calculated using Equations (11) and (12) is the maximum dosage of solid waste in building materials.

\section{Results and Discussion}

\subsection{Activity Concentration}

The average values of the activity concentration of six nuclides for seven samples were calculated and are illustrated in Table 4. It can be concluded that the seven industrial solid wastes all contained ${ }^{238} \mathrm{U},{ }^{235} \mathrm{U},{ }^{232} \mathrm{Th},{ }^{226} \mathrm{Ra},{ }^{210} \mathrm{~Pb}$, and ${ }^{40} \mathrm{~K}$. The activity concentrations of ${ }^{40} \mathrm{~K}$ were relatively high in EMR, EMR-Na, PS, and FA, with values of $443.8,423.9,529.4$, and $461.0 \mathrm{~Bq} / \mathrm{kg}$, respectively. In FA, RM, and PS, the activity concentrations of ${ }^{226}$ Ra were relatively higher than those of the other samples, at 208.2, 462.7 , and $187.4 \mathrm{~Bq} / \mathrm{kg}$, respectively. The activity concentrations of ${ }^{232} \mathrm{Th}$ in FA and RM were as high as 165.6 and $457.7 \mathrm{~Bq} / \mathrm{kg}$, respectively. In addition, activity concentrations of ${ }^{238} \mathrm{U}$ in FA, RM, and PS were higher than those in other solid wastes, which were $234.9,513.0$, and $199.8 \mathrm{~Bq} / \mathrm{kg}$, respectively. On the contrary, the contents of ${ }^{210} \mathrm{~Pb}$ and ${ }^{235} \mathrm{U}$ were very low in all samples. Furthermore, when $\mathrm{NaOH}$ and $\mathrm{Ca}(\mathrm{OH})_{2}$ were used to activate EMR, the activity concentrations of the six nuclides in EMR-Na and EMR-Ca decreased, indicating that the addition of $\mathrm{NaOH}$ and $\mathrm{Ca}(\mathrm{OH})_{2}$ can weaken the radioactivity of EMR.

Table 4. The activity concentrations $(\mathrm{Bq} / \mathrm{kg})$ of six nuclides for the seven solid wastes.

\begin{tabular}{ccccccc}
\hline \multirow{2}{*}{$\begin{array}{c}\text { Name of Solid } \\
\text { Wastes }\end{array}$} & \multicolumn{7}{c}{ Activity Concentration (Bq/kg) } \\
\cline { 2 - 7 } & ${ }^{\mathbf{4 0}} \mathbf{K}$ & ${ }^{\mathbf{2 1 0}} \mathbf{P b}$ & ${ }^{\mathbf{2 2 6}} \mathbf{R a}$ & ${ }^{\mathbf{2 3 2}} \mathbf{T h}$ & ${ }^{\mathbf{2 3 5}} \mathbf{U}$ & ${ }^{{ }^{238} \mathbf{U}}$ \\
\hline PS & $461.0 \pm 23.6$ & $15.1 \pm 9.9$ & $187.4 \pm 5.8$ & $233.7 \pm 9.6$ & $9.1 \pm 0.3$ & $199.8 \pm 17.9$ \\
RM & $259.5 \pm 18.9$ & $324.8 \pm 18.1$ & $462.7 \pm 14.5$ & $457.7 \pm 13.4$ & $22.4 \pm 0.7$ & $513.0 \pm 43.1$ \\
FA & $529.4 \pm 31.1$ & $210.5 \pm 11.8$ & $208.2 \pm 7.0$ & $165.6 \pm 5.6$ & $10.1 \pm 0.3$ & $234.9 \pm 27.2$ \\
PG & $3.3 \pm 6.0$ & $86.0 \pm 4.8$ & $61.0 \pm 2.1$ & $2.3 \pm 0.5$ & $2.7 \pm 0.1$ & $28.0 \pm 13.0$ \\
EMR & $443.8 \pm 26.7$ & $34.3 \pm 2.3$ & $26.6 \pm 1.6$ & $24.8 \pm 1.7$ & $1.6 \pm 0.1$ & $48.3 \pm 15.9$ \\
EMR-Na & $423.9 \pm 25.9$ & $45.9 \pm 2.9$ & $24.5 \pm 1.6$ & $22.2 \pm 1.5$ & $1.5 \pm 0.1$ & $37.9 \pm 15.7$ \\
EMR-Ca & $321.4 \pm 20.9$ & $37.7 \pm 2.5$ & $21.1 \pm 1.5$ & $20.9 \pm 1.6$ & $1.3 \pm 0.1$ & $39.8 \pm 15.8$ \\
\hline
\end{tabular}

\subsection{The Source Analysis of Uranium}

The analysis of the relationship between ${ }^{238} \mathrm{U}$ and ${ }^{235} \mathrm{U}$ and ${ }^{226} \mathrm{Ra}$ can be used to trace the source of the radioactive contamination by uranium in the environment. The activity concentrations of ${ }^{238} \mathrm{U}$ were plotted against the activity concentrations of ${ }^{235} \mathrm{U}$ and ${ }^{226} \mathrm{Ra}$, as shown in Figure 1 . The ratios of ${ }^{238} \mathrm{U} /{ }^{235} \mathrm{U}$ and ${ }^{238} \mathrm{U} /{ }^{226} \mathrm{Ra}$ were calculated and are shown in Table 4. As shown in Figure 1a, the linear 
fitting of the graph shows a good correlation between ${ }^{238} U$ and ${ }^{235} U\left(R^{2}=0.990\right)$. From the natural isotope abundance of uranium isotopes $\left({ }^{238} \mathrm{U}\right.$ is $99.2 \%,{ }^{235} \mathrm{U}$ is $0.72 \%$ ) and its half-life, it is well known that naturally occurring uranium has a constant ${ }^{238} \mathrm{U} /{ }^{235} \mathrm{U}$ activity ratio of 21.7 [58]. The results given in Table 4 indicate that the ratios of ${ }^{238} \mathrm{U} /{ }^{235} \mathrm{U}$ for the seven samples vary from 10.37 to 30.62 , and the ${ }^{238} \mathrm{U} /{ }^{235} \mathrm{U}$ of PG is the lowest at 10.37. The ratio of PS, RM, and FA is close to the constant value, while the ${ }^{238} \mathrm{U} /{ }^{235} \mathrm{U}$ of EMR, EMR-Na, and EMR-Ca are all higher than 21.7. The reason for the deviation may be the higher uncertainty values caused by the self-absorption effect. Additionally, the emanation of radon from the sealed samples may also cause an underestimation of uranium activity concentrations [59]. As $\mathrm{CaO}, \mathrm{SiO}_{2}, \mathrm{Al}_{2} \mathrm{O}_{3}$ are the major components in PS, RM, FA, and PG, according to the literature, the accumulations of $U$ are often associated with clays because the clay fraction has an affinity for absorbing $U ;{ }^{238} \mathrm{U}$ may be easily enriched in clay minerals from the perspective of adsorption [60]. PS, RM, FA, and PG are obtained in the process of calcination, coal alumina, dissolution combustion, and phosphoric acid production, thus the adsorption of clay minerals may have little effect on uranium migration.

As shown in Table 5, the ratios of ${ }^{238} \mathrm{U} /{ }^{226} \mathrm{Ra}$ for the seven solid wastes varied from 0.46 to 1.88 , and the concentrations of ${ }^{238} \mathrm{U}$ were commonly lower than ${ }^{226} \mathrm{Ra}$. The reason for this may be that ${ }^{238} \mathrm{U} /{ }^{226} \mathrm{Ra}$ was disturbed in favor of ${ }^{226} \mathrm{Ra}$ [59]. As shown in Figure $1 \mathrm{~b}$, the linear fitting of the graph shows a good correlation $\left(\mathrm{R}^{2}=0.985\right)$, and the slope of the line has a value $(1.09)$ close to the average value of 1.29 for ${ }^{238} \mathrm{U} /{ }^{226} \mathrm{Ra}$ activity ratios. This indicates that there may exist a radioactive balance between ${ }^{238} \mathrm{U}$ and ${ }^{226} \mathrm{Ra}$. According to previous literature reports, there is depleted uranium pollution in addition to natural uranium in the sample when the ${ }^{238} \mathrm{U} /{ }^{226}$ Ra ratio is greater than 5 [61]. Based on this information, it may be concluded that the uranium contents in the measured seven samples are all of natural origin.
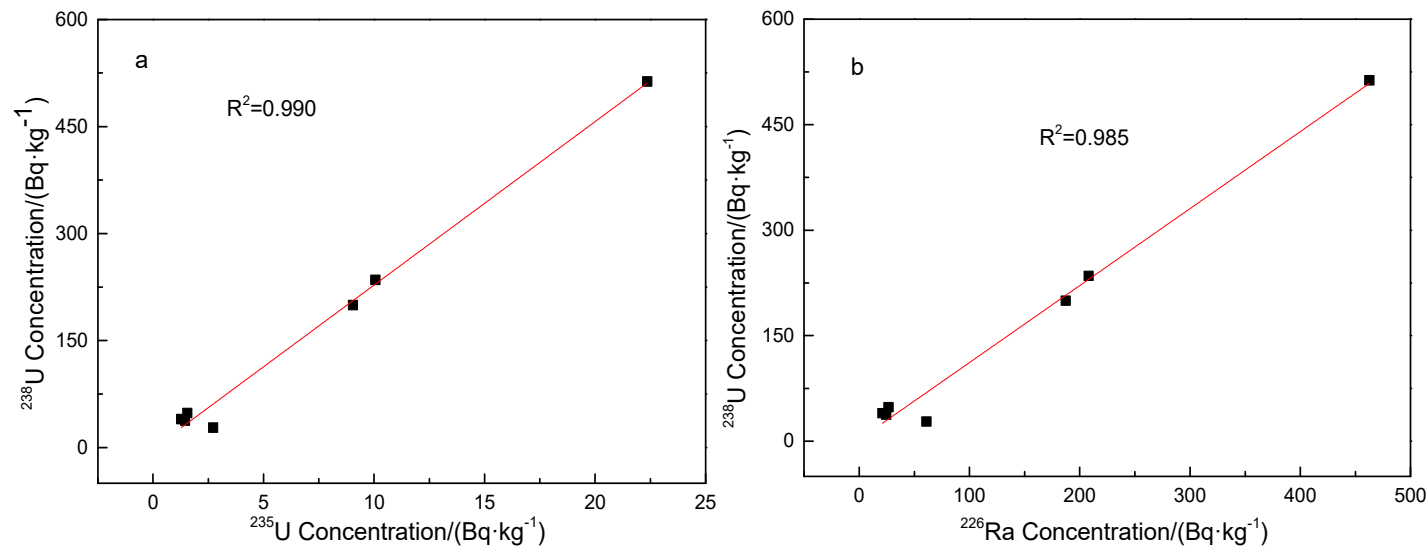

Figure 1. Variation of ${ }^{238} \mathrm{U}$ activity concentration versus (a) ${ }^{235} \mathrm{U}$ activity and (b) ${ }^{226} \mathrm{Ra}$ activity.

Table 5. The activity ratio for different samples under investigation.

\begin{tabular}{ccc}
\hline Name of Solid Wastes & ${ }^{238} \mathbf{U} /{ }^{\mathbf{2 3 5}} \mathbf{U}$ & ${ }^{{ }^{238}} \mathbf{U} /{ }^{\mathbf{2 2 6}} \mathbf{R a}$ \\
\hline PS & 21.96 & 1.07 \\
RM & 22.90 & 1.11 \\
FA & 23.26 & 1.13 \\
PG & 10.37 & 0.46 \\
EMR & 30.19 & 1.82 \\
EMR-Na & 25.27 & 1.54 \\
EMR-Ca & 30.62 & 1.88 \\
\hline
\end{tabular}




\subsection{Radiological Impact Assessment}

\subsubsection{Analysis of Radiation Hazard Indexes}

The $I_{\mathrm{Ra}}, I_{\gamma}, R a_{\mathrm{eq}}, D_{\mathrm{in}}, D_{\mathrm{out}}, E_{\mathrm{in}}$, and $E_{\mathrm{out}}$ were calculated according to the activity concentrations of the radionuclides of the seven solid wastes and Equations (1)-(7). As illustrated in Table 6, the $I_{\mathrm{Ra}}$ and $I_{\gamma}$ of the seven industrial solid wastes were $0.11-2.31$ and $0.17-3.07 \mathrm{~Bq} / \mathrm{kg}$, respectively, of which PS, PG, EMR, EMR-Na, and EMR-Ca were all less than 1 . The $I_{\mathrm{Ra}}$ was greater than 1 and the $I_{\gamma}$ was greater than 1.3 for FA. The $I_{\mathrm{Ra}}$ and $I_{\gamma}$ of the RM were both greater than 2 . According to Table 7, "Limited Standards for Radionuclide of Building Materials", PS, PG, EMR, EMR-Na, and EMR-Ca can be directly used as building materials and decorative materials of class A, B, and C. FA can be used as decoration materials of class $B$ and class $C$. This means that almost all samples are safe for use as they meet the PRC National Standard. Adding FA and RM in building materials should be considered.

According to Table 6, the $R a_{\mathrm{eq}}$ values of the seven samples were between 64.54 and $1137.18 \mathrm{~Bq} / \mathrm{kg}$, among which the $R a_{\mathrm{eq}}$ of PG, EMR, EMR-Na, and EMR-Ca were lower than the world's recommended limit $\left(370 \mathrm{~Bq} / \mathrm{kg}\right.$ ) for building materials [56]. The $R a_{\mathrm{eq}}$ values of the RM, PS, and FA were as high as $1137.18,557.03$, and $485.78 \mathrm{~Bq} / \mathrm{kg}$, respectively. Therefore, the dosage of RM, PS, and FA should be considered when used as the source for building materials.

It also can be seen from Table 6 that the $D_{\text {in }}$ and $D_{\text {out }}$ of the seven industrial solid wastes were 6.38-888.07 and 29.70-501.03 nGy/h, respectively. Specifically, the $D_{\text {in }}$ of PS, RM, and FA were as high as $404.67,888.07$, and $354.49 \mathrm{nGy} / \mathrm{h}$, respectively, while their $D_{\text {out }}$ values were $246.93,501.03$, and $218.29 \mathrm{nGy} / \mathrm{h}$, respectively. These values are higher than the world's average values (i.e., $84 \mathrm{nGy} / \mathrm{h}$ for $D_{\text {in }}$ and $59 \mathrm{nGy} / \mathrm{h}$ for $\left.D_{\text {out }}[56,62]\right)$. The results show that the values of the annual effective dose rate for the seven samples were $0.03-4.36 \mathrm{mSv} / \mathrm{y}$ for $E_{\mathrm{in}}$ and $0.04-0.61 \mathrm{mSv} / \mathrm{y}$ for $E_{\text {out }}$. The values of $E_{\mathrm{in}}$ and $E_{\text {out }}$ for PS, RM, and FA were all higher than the world's recommended values (i.e., $0.4 \mathrm{mSv} / \mathrm{y}$ for $E_{\text {in }}$ and $0.07 \mathrm{mSv} / \mathrm{y}$ for $\left.E_{\text {out }}[56]\right)$.

In summary, the radioactive levels of RM, FA, and PS exceed the "Limited Standards for the Radionuclide of Building Materials", and they cannot be directly used for building materials, while the PG, EMR, EMR-Na, and EMR-Ca could be directly used for building materials within the recommended levels.

Table 6. The $I_{\mathrm{Ra}}, I_{\gamma}, R a_{\mathrm{eq}}, D_{\mathrm{in}}, D_{\mathrm{out}}, E_{\mathrm{in}}$, and $E_{\mathrm{out}}$ for industrial solid wastes.

\begin{tabular}{cccccccc}
\hline $\begin{array}{c}\text { Solid } \\
\text { Wastes }\end{array}$ & $\begin{array}{c}\boldsymbol{I}_{\mathbf{R a}} \\
\mathbf{( B q} / \mathbf{k g})\end{array}$ & $\left.\boldsymbol{I}_{\boldsymbol{\gamma}} \mathbf{( B q} / \mathbf{k g}\right)$ & $\begin{array}{c}\boldsymbol{R} \boldsymbol{a}_{\mathbf{e q}} \\
\mathbf{( B q} / \mathbf{k g})\end{array}$ & $\begin{array}{c}\boldsymbol{D}_{\text {in }} \\
(\mathbf{n G y / h )}\end{array}$ & $\begin{array}{c}\boldsymbol{D}_{\text {out }} \\
(\mathbf{n G y / h})\end{array}$ & $\begin{array}{c}E_{\text {in }} \\
(\mathbf{m S v} / \mathbf{y})\end{array}$ & $\begin{array}{c}E_{\text {out }} \\
(\mathbf{m S v} / \mathbf{y})\end{array}$ \\
\hline PS & 0.94 & 0.71 & 557.03 & 404.67 & 246.93 & 1.98 & 0.30 \\
RM & 2.31 & 3.07 & 1137.18 & 888.07 & 501.03 & 4.36 & 0.61 \\
FA & 1.04 & 1.33 & 485.78 & 354.49 & 218.29 & 1.74 & 0.27 \\
PG & 0.30 & 0.17 & 64.54 & $-3.19 *$ & 29.70 & $-0.02 *$ & 0.04 \\
EMR & 0.13 & 0.27 & 96.23 & 25.60 & 45.77 & 0.13 & 0.06 \\
EMR-Na & 0.12 & 0.25 & 88.99 & 19.28 & 42.45 & 0.09 & 0.05 \\
EMR-Ca & 0.11 & 0.21 & 75.78 & 6.38 & 35.80 & 0.03 & 0.04 \\
\hline
\end{tabular}

* The minus sign represents that the $D_{\text {in }}$ of PG is lower than the natural radiation background value.

Table 7. Limited Standards for the Radionuclide of Building Materials (GB/6566-2010) [43].

\begin{tabular}{cccccc}
\hline \multirow{2}{*}{$\begin{array}{c}\text { Standard } \\
\text { Name }\end{array}$} & \multicolumn{2}{c}{ Building Materials } & \multicolumn{2}{c}{ Decoration Materials } \\
\cline { 2 - 5 } & Hollow Rate $\leq \mathbf{2 5 \%}$ & Hollow Rate $\mathbf{2 5 \%}$ & Class A & Class B & Class C \\
\hline \multirow{2}{*}{$\begin{array}{c}\text { Radionuclide } \\
\text { limit }\end{array}$} & $I_{\mathrm{R}_{\mathrm{a}}} \leq 1.0$ & $I_{\mathrm{R}_{\mathrm{a}} \leq 1.0}$ & $I_{\mathrm{R}_{\mathrm{a}}} \leq 1.0$ & $I_{\mathrm{R}_{\mathrm{a}}} \leq 1.3$ & $I_{\mathrm{r}} \leq 2.8$ \\
\hline
\end{tabular}




\subsubsection{Contribution Analysis of Nuclides to Radiation}

According to Equations (1)-(7), the contribution of radionuclides ${ }^{26} \mathrm{Ra},{ }^{232} \mathrm{Th}$, and ${ }^{40} \mathrm{~K}$ to radiation hazard indexes varies in different solid wastes. The contributions of ${ }^{26} \mathrm{Ra},{ }^{232} \mathrm{Th}$, and ${ }^{40} \mathrm{~K}$ to $I_{\gamma}$, $R a_{\text {eq }}, D_{\text {in }}, E_{\text {in }}, D_{\text {out }}$, and $E_{\text {out }}$ were calculated and plotted in Figure 2 . As shown in Figure $2,{ }^{226} \mathrm{Ra}$ was the main contributor to $I_{\gamma}, R a_{\mathrm{eq}}, D_{\mathrm{in}}, E_{\mathrm{in}}, D_{\mathrm{out}}$, and $E_{\mathrm{out}}$ in RM, FA, and PG, and the relative contributions of ${ }^{226} \mathrm{Ra}$ were in the range of $40.69-44.80 \%$ for RM, $42.44-45.97 \%$ for FA, and $92.44-95.19 \%$ for PG. Similarly, ${ }^{232} \mathrm{Th}$ was the main contributor to $I_{\gamma}, R a_{\mathrm{eq}}, D_{\mathrm{in}}, E_{\mathrm{in}}, D_{\mathrm{out}}$, and $E_{\text {out }}$ in PS, RM, and FA, and the relative contributions of ${ }^{232} \mathrm{Th}$ varied from 55.07 to $59.99 \%$ for PS, 52.98 to $57.55 \%$ for RM, and 43.73 to $48.76 \%$ for FA. However, the relative contributions of ${ }^{40} \mathrm{~K}$ to $I_{\gamma}, R a_{\mathrm{eq}}, D_{\text {in }}, E_{\text {in }}, D_{\text {out }}$, and $E_{\text {out }}$ in EMR, EMR-Na, and EMR-Ca were in the range of 35.51-41.00\%, 36.68-42.19\%, and 32.66-38.02\%, respectively. This data shows that ${ }^{226} \mathrm{Ra}$ and ${ }^{232} \mathrm{Th}$ were the main contributors to radiation hazard indexes in PS, RM, FA, and PG, while the contributions of ${ }^{226} \mathrm{Ra},{ }^{232} \mathrm{Th}$, and ${ }^{40} \mathrm{~K}$ in EMR, EMR-Na, and EMR-Ca were relatively balanced. However, the phase analysis of known nuclides in those aforementioned solid wastes has not been covered in this study, and future research should focus on the removal or decrease of the nuclides in different phases.
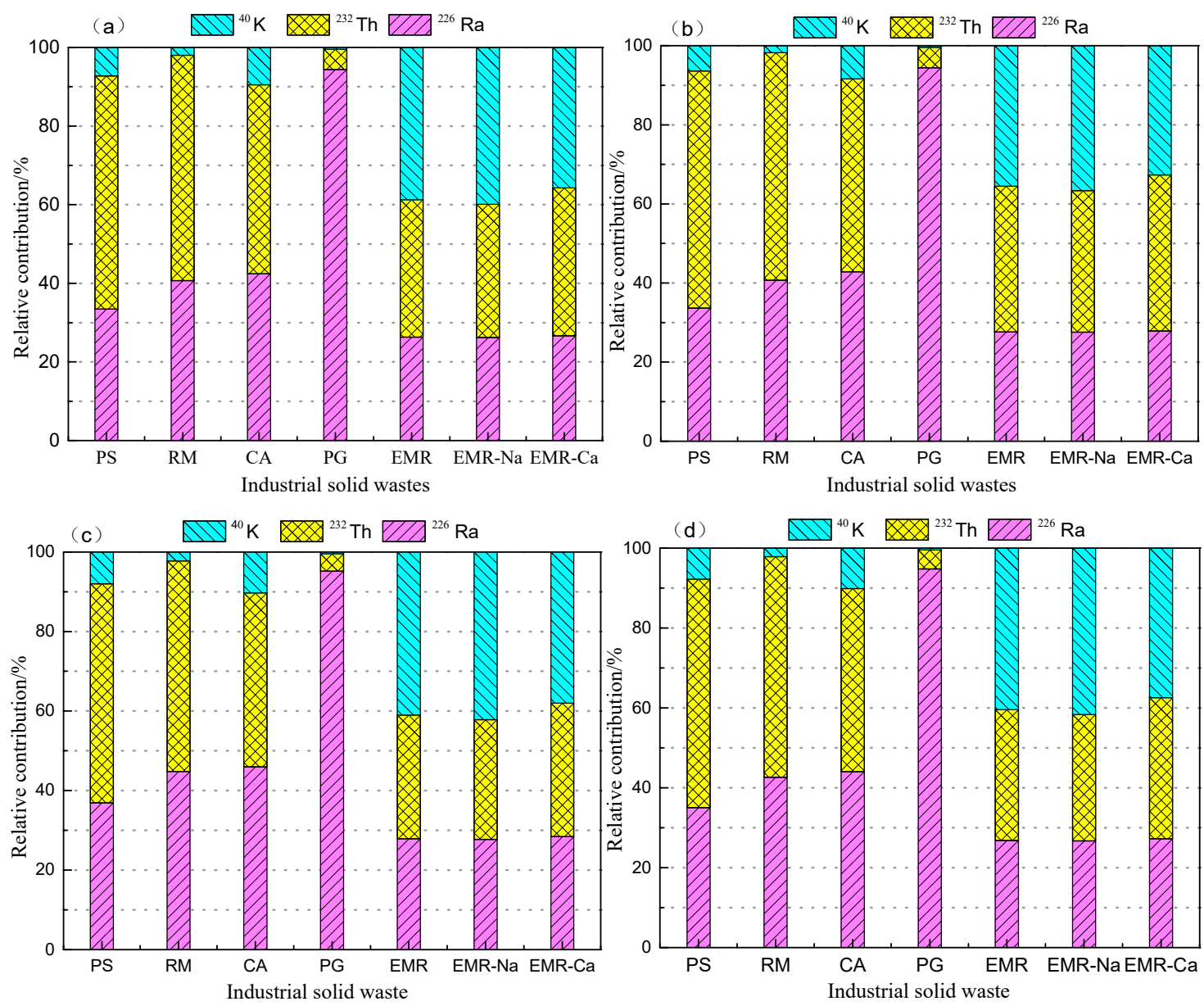

Figure 2. The relative concentrations of ${ }^{226} \mathrm{Ra},{ }^{232} \mathrm{Th}$, and ${ }^{40} \mathrm{~K}$ in $(\mathbf{a}) I_{\gamma},(\mathbf{b}) R a_{\mathrm{eq}},(\mathbf{c}) D_{\text {in }}$ and $E_{\text {in }}(\mathbf{d}) D_{\text {out }}$ and $E_{\text {out }}$ in industrial solid wastes.

\subsubsection{Limitation Analysis of Solid Wastes in Building Materials}

As the solid wastes RM, FA, and PS cannot be directly used for building materials, the maximum dosages $\left(\mathrm{f}_{\mathrm{s}}\right)$ of solid wastes FA, RM, and PS in building materials were calculated using Equations (11) and (12) with results of $75.44 \%, 29.72 \%$, and $66.01 \%$, respectively. According to the different related research reviews related, increasing the addition of FA in concrete can result in a decrease 
in the compressive strength of concrete. The optimum FA percentages were found to be $10 \%, 20 \%$, $22 \%$, and $35 \%$ in various studies [63-66]. Similarly, previous research showed that the corrosion rate of concrete is the lowest between $20 \mathrm{wt}$. \% and $30 \mathrm{wt}$. \% of added RM content [67]. Other studies showed that the addition of RM in amounts greater than $20 \%$ causes a decrease in the hydration temperature and results in a decrease in the compressive strength [68]. Therefore, in terms of the mechanical properties of building materials, the optimum addition of FA, RM, and PS in building materials will not exceed the maximum addition allowed by their radioactivity level. That is, FA, RM, and PS can be used even if their radioactivity levels are above the standard limits.

\section{Conclusions}

(1) ${ }^{40} \mathrm{~K},{ }^{226} \mathrm{Ra},{ }^{232} \mathrm{Th}$, and ${ }^{238} \mathrm{U}$ are the main nuclides in $\mathrm{FA}, \mathrm{RM}$, and $\mathrm{PS} .{ }^{210} \mathrm{~Pb}$ and ${ }^{226} \mathrm{Ra}$ are the main nuclides in PG, while ${ }^{40} \mathrm{~K}$ is the main nuclide in EMR, EMR-Na, and EMR-Ca. The uranium contents of all samples are all from natural uranium.

(2) The values of $I_{\mathrm{Ra}}$ and $I_{\gamma}$ were all less than 1 except for FA $\left(I_{\mathrm{Ra}}>1\right.$ and $\left.I_{\gamma}>1.3\right)$ and RM $\left(I_{\mathrm{Ra}}>2\right.$ and $\left.I_{\gamma}>2\right)$, and the values of $R a_{\mathrm{eq}}, D_{\mathrm{in}}, D_{\mathrm{out}}, E_{\mathrm{in}}$, and $E_{\mathrm{out}}$ were higher than the world's recommended values (i.e., $370 \mathrm{~Bq} / \mathrm{kg}, 84 \mathrm{nGy} / \mathrm{h}, 59 \mathrm{nGy} / \mathrm{h}, 0.4 \mathrm{mSv} / \mathrm{y}$, and $0.07 \mathrm{mSv} / \mathrm{y}$, respectively) for PS, $\mathrm{RM}$, and FA due to higher concentrations of ${ }^{226} \mathrm{Ra}$ and ${ }^{232} \mathrm{Th}$.

(3) PG, EMR, EMR-Na, and EMR-Ca could be used for building materials unlimitedly. However, RM, FA, and PS could be used as additive or auxiliary materials for building materials by means of doping and mixing, with maximum portions of $75.44 \%, 29.72 \%$, and $66.01 \%$, respectively. These findings provide a basis for the restriction of the aforementioned solid wastes in Guizhou in the field of building materials. Further research on the phase analysis and treatment of known nuclides in solid wastes are necessary in the future.

Author Contributions: Z.S. and Q.Z. conceived and designed the experiments; Z.S. performed the experiments; Q.Z. contributed the analysis resource; W.C. and Q.C. helped to analyze the data; Z.S. wrote the paper.

Funding: This study was founded by the Science and Technology Program of Guizhou Province, China (Qian Ke He Support [2017]2040) and the Major Special Projects of Guizhou Province, China (Qian Ke He [20116023].

Conflicts of Interest: The authors declare no conflict of interest.

\section{References}

1. Zhang, Y.H.; Wang, X.K.; Lu, F.Z. Study progress of alkali removal from red mud and novel functional materials (in Chinese). Chin. J. Environ. Eng. 2016, 10, 3383-3390.

2. 2017 Annual Report on Prevention and Control of Solid Waste in China's Large and Medium-Sized Cities (In Chinese); Environmental Protection: Beijing, China, 2018; pp. 90-106.

3. Matiullah; Ahad, A.; Rehman, S.U.; Rehman, S.U.; Faheem, M. Measurement of radioactivity in the soil of Bahawalpur division, Pakistan. Radiat. Prot. Dosim. 2004, 112, 443. [CrossRef] [PubMed]

4. Mehra, R.; Singh, S.; Singh, K.; Sonkawade, R. ${ }^{226} \mathrm{Ra},{ }^{232} \mathrm{Th}$ and ${ }^{40} \mathrm{~K}$ analysis in soil samples from some areas of Malwa region, Punjab, India using gamma ray spectrometry. Environ. Monit. Assess. 2007, 134, 333-342. [CrossRef] [PubMed]

5. Ahmad, N.; Matiullah; Khatibeh, A.J.A.H.; Ma'Ly, A.; Kenawy, M.A. Measurement of natural radioactivity in Jordanian sand. Radiat. Meas. 1997, 28, 341-344. [CrossRef]

6. Khatibeh, A.J.A.H.; Ahmad, N.; Matiullah; Kenawy, M.A. Natural radioactivity in marble stones- Jordan. Radiat. Meas. 1997, 28, 345-348. [CrossRef]

7. Bruzzi, L.; Baroni, M.; Mele, R.; Nanni, E. Proposal for a method of certification of natural radioactivity in building materials. J. Radiol. Prot. 1997, 17, 85. [CrossRef]

8. Chiozzi, P.; De, F.P.; Fazio, A.; Pasquale, V.V.; Verdoya, M. Laboratory application of NaI (Tl) gamma-ray spectrometry to studies of natural radioactivity in geophysics. Appl. Radiat. Isot. 2000, 53, 127-132. [CrossRef]

9. Turhan, S. Assessment of the natural radioactivity and radiological hazards in Turkish cement and its raw materials. J. Environ. Radioact. 2008, 99, 404-414. [CrossRef] 
10. Gupta, M.; Mahur, A.K.; Varshney, R.; Sonkawade, R.G.; Verma, K.D.; Prasad, R. Measurement of natural radioactivity and radon exhalation rate in fly ash samples from a thermal power plant and estimation of radiation doses. Radiat. Meas. 2013, 50, 160-165. [CrossRef]

11. Turhan, S..; Parmaksız, A.; Köse, A.; Yüksel, A.; Arıkan, İ.H.; Yücel, B. Radiological characteristics of pulverized fly ashes produced in Turkish coal-burning thermal power plants. Fuel 2010, 89, 3892-3900. [CrossRef]

12. Kardos, R.; Sas, Z.; Shahrokhi, A.; Somlai, J.; Kovács, T. Radionuclide content of NORM by-products originating from the coal-fired power plant in Oroszlány (Hungary). Radiat. Prot. Dosim. 2015, 167, $266-269$. [CrossRef] [PubMed]

13. Trevisi, R.; Leonardi, F.; Risica, S.; Nuccetelli, C. Updated database on natural radioactivity in building materials in Europe. J. Environ. Radioact. 2018, 187, 90-105. [CrossRef]

14. Lu, X.; Zhang, X. Radionuclide content and associated radiation hazards of building materials and by-products in Baoji, West China. Radiat. Prot. Dosim. 2007, 128, 471-476. [CrossRef] [PubMed]

15. Feng, T.T.; Lu, X.W. Natural radioactivity, radon exhalation rate and radiation dose of fly ash used as building materials in Xiangyang, China. Indoor Built Environ. 2016, 25, 626-634. [CrossRef]

16. Cooper, M.B.; Clarke, P.C.; Robertson, W.; Mcpharlin, I.R.; Jeffrey, R.C. An investigation of radionuclide uptake into food crops grown in soils treated with bauxite mining residues. J. Radioanal. Nuclear Chem. 1995, 194, 379-387. [CrossRef]

17. Pinnock, W.R. Measurements of radioactivity in Jamaican building materials and gamma dose equivalents in a prototype red mud house. Health Phys. 1991, 61, 647-651. [CrossRef] [PubMed]

18. Gezer, F.; Turhan, Ş.; Uğur, F.A.; Gören, E.; Kurt, M.Z.; Ufuktepe, Y. Natural radionuclide content of disposed phosphogypsum as TENORM produced from phosphorus fertilizer industry in Turkey. Ann. Nuclear Energy 2012, 50, 33-37. [CrossRef]

19. Alam, M.N.; Chowdhury, M.I.; Kamal, M.; Ghose, S.; Banu, H.; Chakraborty, D. Radioactivity in chemical fertilizers used in Bangladesh. Appl. Radiat. Isot. 1997, 48, 1165-1168. [CrossRef]

20. Mourad, N.M.; Sharshar, T.; Elnimr, T.; Mousa, M.A. Radioactivity and fluoride contamination derived from a phosphate fertilizer plant in Egypt. Appl. Radiat. Isot. 2009, 67, 1259-1268. [CrossRef]

21. Al-Jundi, J.; Al-Ahmad, N.; Shehadeh, H.; Afaneh, F.; Maghrabi, M.; Gerstmann, U.; Hã Llriegl, V.; Oeh, U. Investigations on the activity concentrations of ${ }^{238} \mathrm{U},{ }^{226} \mathrm{Ra},{ }^{228} \mathrm{Ra},{ }^{210} \mathrm{~Pb}$ and ${ }^{40} \mathrm{~K}$ in Jordan phosphogypsum and fertilizers. Radiat. Prot. Dosim. 2008, 131, 449-454. [CrossRef]

22. Song, M.H.; Chang, B.U.; Koh, S.M.; Kim, Y.J.; Kim, D.J.K.G. Overall natural radioactivity of a phosphate fertilizer industry in Korea. Radioprotection 2012, 46, S113-S118. [CrossRef]

23. Kovler, K.; Haquin, G.; Manasherov, V.; Ne'Eman, E.; Lavi, N. Natural radionuclides in building materials available in Israel. Build. Environ. 2002, 37, 531-537. [CrossRef]

24. Dueñas, C.; Fernández, M.C.; Cañete, S.; Pérez, M. Radiological impacts of natural radioactivity from phosphogypsum piles in Huelva (Spain). Radiat. Meas. 2010, 45, 242-246. [CrossRef]

25. Msila, X.; Labuschagne, F.; Barnard, W.; Billing, D.G. Radioactive nuclides in phosphogypsum from the lowveld region of South Africa. S. Afr. J. Sci. 2016, 112, 1-5. [CrossRef]

26. Kovács, T.; Shahrokhi, A.; Sas, Z.; Vigh, T.; Somlai, J. Radon exhalation study of manganese clay residue and usability in brick production. J. Environ. Radioact. 2017, 168, 15-20. [CrossRef] [PubMed]

27. Du, B.; Zhou, C.; Dan, Z.; Luan, Z.; Duan, N. Preparation and characteristics of steam-autoclaved bricks produced from electrolytic manganese solid waste. Constr. Build. Mater. 2014, 50, 291-299. [CrossRef]

28. Taoufiq, L.; Laamyem, A.; Boukhair, A.; Essediqi, E.; Monkade, M.; Zrabda, A. Radiological assessment of wastewater treatment processes based on the use of coal ashes as a filters. J. Radiat. Res. Appl. Sci. 2018. [CrossRef]

29. NBSC. 2013 China Statistical Yearbook (in Chinese); China Statistics Press: Beijing, China, 2013; pp. $278-279$. ISBN 9787503769634.

30. NBSC. 2014 China Statistical Yearbook (in Chinese); China Statistics Press: Beijing, China, 2014; pp. $227-228$. ISBN 9787503772801.

31. NBSC. 2015 China Statistical Yearbook (in Chinese); China Statistics Press: Beijing, China, 2015; pp. 251-252. ISBN 9787503776380.

32. NBSC. 2016 China Statistical Yearbook (in Chinese); China Statistics Press: Beijing, China, 2016; pp. $247-248$. ISBN 9787503779176. 
33. NBSC. 2017 China Statistical Yearbook (in Chinese); China Statistics Press: Beijing, China, 2017; pp. $241-242$. ISBN 978-7-5037-8253-4.

34. NBSC. 2018 China Statistical Yearbook (in Chinese); China Statistics Press: Beijing, China, 2018; pp. $250-251$. ISBN 9787503785870.

35. Li, X.; Ye, J.; Liu, Z.; Qiu, Y.; Li, L.; Mao, S.; Wang, X.; Zhang, Q. Microwave digestion and alkali fusion assisted hydrothermal synthesis of zeolite from coal fly ash for enhanced adsorption of Cd(II) in aqueous solution. J. Cent. South Univ. 2018, 25, 9-20. [CrossRef]

36. Li, X.; Zhang, Q.; Ke, B.; Wang, X.; Li, L.; Li, X.; Mao, S. Insight into the effect of maleic acid on the preparation of $\alpha$-hemihydrate gypsum from phosphogypsum in $\mathrm{Na}_{2} \mathrm{SO}_{4}$ solution. J. Cryst. Growth 2018, 493, 34-40. [CrossRef]

37. Croymans, T.; Vandael Schreurs, I.; Hult, M.; Marissens, G.; Lutter, G.; Stroh, H.; Schreurs, S.; Schroeyers, W. Variation of natural radionuclides in non-ferrous fayalite slags during a one-month production period. J. Environ. Radioact. 2017, 172, 63-73. [CrossRef]

38. Hegedûs, M.; Tóth-Bodrogi, E.; Jónás, J.; Somlai, J.; Kovács, T. Mobility of ${ }^{232} \mathrm{Th}$ and ${ }^{210}$ Po in red mud. J. Environ. Radioact. 2018, 184-185, 71-76. [CrossRef] [PubMed]

39. Santos, A.J.G.; Silva, P.S.C.; Mazzilli, B.P.; Fávaro, D.I.T. Radiological characterisation of disposed phosphogypsum in Brazil: Evaluation of the occupational exposure and environmental impact. Radiat. Prot. Dosim. 2006, 121, 179-185. [CrossRef] [PubMed]

40. Lauer, N.E.; Hower, J.C.; Hsu-Kim, H.; Taggart, R.K.; Vengosh, A. Naturally occurring radioactive materials in coals and coal combustion residuals in the united states. Environ. Sci. Technol. 2015, 49, 11227-11233. [CrossRef] [PubMed]

41. Ebaid, Y.Y. Use of Gamma-Ray spectrometry for uranium isotopic analysis in environmental samples. Rom. J. Phys. 2010, 55, 69-74.

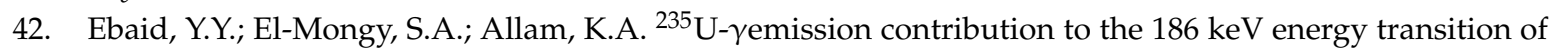
${ }^{226} \mathrm{Ra}$ in environmental samples activity calculations. Int. Congr. Ser. 2005, 1276, 409-411. [CrossRef]

43. AQAIQ; SAC. Limits of Radionuclides in Building Materials GB 6566-2010 (In Chinese); AQSIQ, SAC: Beijing, China, 2010; pp. 1-3.

44. Lu, X.; Chao, S.; Yang, F. Determination of natural radioactivity and associated radiation hazard in building materials used in Weinan, China. Radiat. Phys. Chem. 2014, 99, 62-67. [CrossRef]

45. Hamilton, E.I. The relative radioactivity of building materials. Am. Ind. Hyg. Assoc. J. 1971, $32,398$. [CrossRef]

46. Matthew, P.J. Natural radioactivity of Australian building materials, industrial wastes and by-products. Health Phys. 1985, 48, 87. [CrossRef]

47. Stojanovska, Z.; Nedelkovski, D.; Ristova, M. Natural radioactivity and human exposure by raw materials and end product from cement industry used as building materials. Radiat. Meas. 2010, 45, 969-972. [CrossRef]

48. NEA-OECD. Exposure to Radiation from the Natural Radioactivity in Building Materials: Report by a Group of Exports of the OECD Nuclear Energy Agency; NEA-OECD: Paris, France, 1979; pp. 13-19.

49. Yu, K.N.; Guan, Z.J.; Stokes, M.J.; Young, E.C.M. The assessment of the natural radiation dose committed to the Hong Kong people. J. Environ. Radioact. 1992, 17, 31-48. [CrossRef]

50. Hayumbu, P.; Zaman, M.B.; Lubaba, N.C.H.; Munsanje, S.S.; Muleya, D. Natural radioactivity in Zambian building materials collected from Lusaka. J. Radioanal. Nuclear Chem. 1995, 199, 229-238. [CrossRef]

51. European Commission. Radiological protection principles concerning the natural radioactivity of building materials. Brussels. Radiat. Prot. 1999, 112, 5-16.

52. He, Z.Y.; Luo, G.Z.; Huang, J.J. National survey on natural radioactivity level of environment (1983-1990) (in Chinese). Radiat. Prot. 1992, 12, 81-95.

53. Quindos, L.S.; Fernández, P.L.; Ródenas, C.; Gómez-Arozamena, J.; Arteche, J. Conversion factors for external gamma dose derived from natural radionuclides in soils. J. Environ. Radioact. 2004, 71, 139. [CrossRef]

54. Uosif, M.A.; Eltaher, A. Radiological assessment of Abu-Tartur phosphate, Western Desert Egypt. Radiat. Prot. Dosim. 2008, 130, 228-235. [CrossRef]

55. Billa, J.; Han, F.; Didla, S.; Ankrah, M.; Yu, H.; Dimpah, J.; Brempong, O.; Adzanu, S. Evaluation of radioactivity levels in fertilizers commonly used in the Southern USA. J. Radioanal. Nuclear Chem. 2015, 306, 183-191. [CrossRef] 
56. UNSCEAR. Sources and Effects of Ionizing Radiation: United Nations Scientific Committee on the Effects of Atomic Radiation: UNSCEAR 2000 Report to the General Assembly, with Scientific Annexes; UNSCEAR: New York, NY, USA, 2000; ISBN 9211422388.

57. Uosif, M.A.M.; Mostafa, A.M.A.; Elsaman, R.; Moustafa, E.S. Natural radioactivity levels and radiological hazards indices of chemical fertilizers commonly used in Upper Egypt. J. Radiat. Res. Appl. Sci. 2014, 7, 430-437. [CrossRef]

58. Ivanovich, M.; Harmon, R.S. Uranium-Series Disequilibrium: Applications to Earth, Marine, and Environmental Sciences, 2nd ed.; Clarendon Press and Oxford University Press: Oxford, UK, 1992; p. 571. ISBN 019854278X.

59. El-Bahi, S.M.; Sroor, A.; Mohamed, G.Y.; El-Gendy, N.S. Radiological impact of natural radioactivity in Egyptian phosphate rocks, phosphogypsum and phosphate fertilizers. Appl. Radiat. Isot. 2017, 123, 121-127. [CrossRef]

60. Megumi, K.; Oka, T.; Yaskawa, K.; Sakanoue, M. Contents of natural radioactive nuclides in soil in relation to their surface area. JGR Solid Earth 1982, 87, 10857-10860. [CrossRef]

61. Karangelos, D.J.; Anagnostakis, M.J.; Hinis, E.P.; Simopoulos, S.E.; Zunic, Z.S. Determination of depleted uranium in environmental samples by gamma-spectroscopic techniques. J. Environ. Radioact. 2004, 76, 295-310. [CrossRef]

62. UNSCEAR. Sources and Effects of Ionizing Radiation, V. I: UNSCEAR 2008 Report to the General Assembly with Scientific Annexes; United Nations Publication: New York, NY, USA, 2010; ISBN 978-92-1-142274-0.

63. Lederer, J.; Trinkel, V.; Fellner, J. Wide-scale utilization of MSWI fly ashes in cement production and its impact on average heavy metal contents in cements: The case of Austria. Waste Manag. 2017, 60, 247-258. [CrossRef] [PubMed]

64. Del Valle-Zermeño, R.; Formosa, J.; Chimenos, J.M.; Martínez, M.; Fernández, A.I. Aggregate material formulated with MSWI bottom ash and APC fly ash for use as secondary building material. Waste Manag. 2013, 33, 621-627. [CrossRef]

65. García Arenas, C.; Marrero, M.; Leiva, C.; Solís-Guzmán, J.; Vilches Arenas, L.F. High fire resistance in blocks containing coal combustion fly ashes and bottom ash. Waste Manag. 2011, 31, 1783-1789. [CrossRef] [PubMed]

66. Pan, J.R.; Huang, C.; Kuo, J.; Lin, S. Recycling MSWI bottom and fly ash as raw materials for Portland cement. Waste Manag. 2008, 28, 1113-1118. [CrossRef]

67. Ribeiro, D.V.; Labrincha, J.A.; Morelli, M.R. Effect of the addition of red mud on the corrosion parameters of reinforced concrete. Cem. Concr. Res. 2012, 42, 124-133. [CrossRef]

68. Senff, L.; Hotza, D.; Labrincha, J.A. Effect of red mud addition on the rheological behaviour and on hardened state characteristics of cement mortars. Constr. Build. Mater. 2011, 25, 163-170. [CrossRef]

(C) 2019 by the authors. Licensee MDPI, Basel, Switzerland. This article is an open access article distributed under the terms and conditions of the Creative Commons Attribution (CC BY) license (http:// creativecommons.org/licenses/by/4.0/). 